\title{
DIGLOSIA
}

Terakreditasi Sinta 3 | Volume 3 | Nomor 3 | Tahun 2020 | Halaman 243-252

P-ISSN 2615-725X | E-ISSN 2615-8655

http://diglosiaunmul.com/index.php/diglosia/article/view/60

\section{PENGEMBANGAN BAHAN AJAR MENULIS BERITA PADA SISWA SMP KELAS VIII}

\author{
Developing Writing News Teaching Materials for Eight Grade Junior High School Students
}

\author{
Luise Nenis Putri Mega Marta ${ }^{1, *}$, Mursalim $^{2}$, Bibit Suhatmady $^{2}$ \\ ${ }^{1}$ Magister Pendidikan Bahasa dan Sastra Indonesia, FKIP Universitas Mulawarman \\ ${ }^{2}$ Universitas Mulawarman \\ *Pos-el korespondensi: luisenenis.07@gmail.com
}

\begin{abstract}
The learning process using teaching materials is an effective way for teachers to deliver material to students. This study's teaching materials' development aims to produce teaching materials for writing news texts on eighth-grade junior high school students. The developed teaching material validity is seen from developing, implementing and measuring the effectiveness of the teaching material. The research method used is the Borg and Gall's Research and Development. Data collection techniques used were questionnaires and observations. Data analysis uses descriptive qualitative analysis and descriptive statistical analysis. The process of developing the materials was based on experts' validation of the materials, the language, and the product's graphic. The material experts' validation result showed a value of $77.5 \%$ and $92.5 \%$ in the very feasible category. The linguists' validation results showed a value of $72 \%$ and $92 \%$ in the very feasible category. The graphic experts showed a value of $78 \%$ and 92.8\% included in the very feasible category. In this study, the product trial subjects were students of class VIII of junior high school and were carried out with small class trials and field trials. Through a small group and field test results, the effectiveness of teaching materials from assessing student responses was the average value of 3.23 (82.8\%) on average value or good category. Student learning outcomes show an overall grade point average of $83.8(100 \%)$. This shows that the quality of student learning based on teaching materials in writing news is very good. From the data obtained, the developed teaching materials are suitable for use.
\end{abstract}

Keywords: development of teaching materials, writing news text

Abstrak: Proses pembelajaran menggunakan bahan ajar merupakan cara yang efektif dilakukan guru dalam memberikan materi kepada siswa. Pengembangan bahan ajar dalam penelitian ini bertujuan untuk menghasilkan bahan ajar menulis teks berita pada siswa SMP kelas VIII. Validitas bahan ajar yang dikembangkan dilihat dari proses pengembangan, pelaksanaan dan efektivitas bahan ajar. Metode penelitian yang digunakan adalah Reasearch and Development (R\&D) Borg \& Gall. Teknik pengambilan data yang digunakan adalah penyebaran angket (kuesioner) dan observasi. Analisis data menggunakan analisis deskriptif kualitatif dan analisis statistik deskriptif. Proses pengembangan bahan ajar mengacu pada uji validitas ahli yang dilakukan oleh 3 ahli, yakni ahli materi, ahli bahasa, dan ahli grafika. Hasil validasi dari ahli materi menunjukkan nilai sebesar $77,5 \%$ dan $92,5 \%$ dengan kategori sangat layak. Hasil validasi dari ahli bahasa menunjukkan nilai sebesar $72 \%$ dan $92 \%$ dalam kategori sangat layak, dan hasil validasi dari ahli grafika menunjukkan nilai sebesar $78 \%$ dan $92,8 \%$ masuk dalam kategori sangat layak. Subjek uji coba produk dalam penelitian ini adalah siswa kelas VIII SMP dan dilakukan dengan tahap uji coba kelas kecil dan uji lapangan. Melalui uji kelompok kecil dan lapangan diperoleh hasil efektivitas bahan ajar dari penilaian siswa dengan nilai rata-rata $3,23(82,8 \%)$ kategori baik. Hasil belajar siswa menunjukkan nilai keseluruhan rata-rata 83,8 (100\%) hal ini menunjukkan bahwa kualitas belajar siswa berdasarkan bahan ajar menulis berita masuk dalam kategori sangat baik. Dari data-data yang diperoleh maka bahan ajar yang dikembangkan layak untuk digunakan.

Kata Kunci: pengembangan bahan ajar, menulis teks berita 


\section{A. PENDAHULUAN}

Pembelajaran Bahasa Indonesia tidak terlepas dari empat komponen yang terlibat dalam keterampilan berbahasa yaitu menyimak, berbicara, membaca, dan menulis. Hal ini sependapat dengan Tarigan (2015, hlm. 1) yang menyatakan bahwa empat komponen keterampilan ini harus dikuasai apabila ingin benar-benar terampil berbahasa, karena pada hakikatnya keterampilan itu erat hubungannya dengan proses berpikir yang mendasari bahasa.

Alwasilah dalam Rohmadi \& Yakub (2010, hlm. 4) menyatakan bahwa dibandingkan dengan keterampilan bahasa yang lain, keterampilan menulis merupakan suatu keterampilan berbahasa yang paling sulit penguasaannya. Hal ini karena keterampilan menulis menghendaki penguasaan berbagai unsur kebahasaan dan unsur nonkebahasaan . dalam kaitannya dengan unsur kebahasaan penulis harus menguasai penggunaan tanda baca, diksi, perangkaian kalimat dan penyusunan sebuah paragraf atau tulisan.

Hakikatnya pembelajaran menulis bertujuan agar siswa mampu menuangkan pengalaman dan gagasan, perasaan, dan imajinasinya secara tertulis. Oleh karena itu, kegiatan pembelajaran menulis harus dilaksanakan dengan latihan yang rutin sehingga makin mempertajam kepekaan peserta didik terhadap pola pikirnya serta kesalahan-kesalahan baik ejaan, struktur maupun tentang pemilihan kosa kata Menulis merupakan kegiatan intelektual sekaligus aktivitas fisik yang lumayan menguras tenaga dan pikiran. Roekhan (1991) mengatakan dalam komunikasi tertulis ada empat unsur yang terlibat yaitu penulis sebagai penyampaian pesan, pesan atau tulisan, saluran atau medium tulisan, dan pembaca sebagai penerima pesan.

Berdasarkan pengamatan lapangan yang dilakukan peneliti, siswa SMP kurang berminat untuk mengetahui berita-berita yang ada. Contohnya ketika siswa sedang menonton televisi, ia akan cenderung memilih acara hiburan ataupun film yang dianggap lebih menyenangkan daripada berita. Saat di perpustakaan pun, jarang dijumpai siswa yang membaca koran atau surat kabar dibandingkan siswa yang membaca bukubuku fiksi. Karena alasan tersebut, nilai siswa dalam menulis berita cenderung masih rendah. Jika hal tersebut dibiarkan terus-menerus maka pengetahuan yang dimiliki oleh siswa tidak akan berkembang dan luas.

Berdasarkan hasil wawancara dengan guru mata pelajaran Bahasa Indonesia, pembelajaran menulis teks berita secara singkat, padat, dan jelas belum mencapai hasil yang maksimal. Kendala yang dihadapi oleh guru dalam kegiatan menulis berita, yaitu rendahnya minat siswa terhadap berita dan belum adanya bahan ajar khusus untuk pembelajaran menulis berita. Melalui bahan ajar yang dikembangkan, peneliti mengharapkan agar siswa makin tertarik pada berita dan termotivasi untuk kreatif menghasilkan produk berita. Selain itu, pemahaman multikultural siswa diharapkan bertambah sehingga wawasan kebangsaan siswa pun makin luas. Dalam penelitian ini, peneliti akan mengembangkan bahan ajar menulis berita peristiwa multikultural dengan pendekatan kontekstual untuk siswa SMP kelas VIII.

Penelitian dalam bidang pendidikan seperti penelitian menulis berita sudah banyak dilakukan oleh peneliti lain. Perbedaan antara penelitian satu dengan yang lain terletak pada jenis penelitian dan model atau metode yang digunakan. Penelitian tersebut pernah dilakukan oleh Yulianti (2011) dalam penelitian berjudul "Peningkatan Keterampilan Menulis Teks Berita Menggunakan Model Investigasi Kelompok dengan Pemanfaatan Media Foto 
Peristiwa pada Siswa Kelas VIII F SMP Negeri 28 Semarang" menunjukkan bahwa terdapat peningkatan keterampilan siswa dalam menulis teks berita dengan menggunakan pengamatan foto peristiwa. Kemudian pada penelitian "Peningkatan Keterampilan Menulis Teks Berita Melalui Strategi Menulis Di Sini dan Saat Ini (DS-SI) dengan Teknik Inkuiri Menggunakan Media Foto Jurnalistike Siswa Kelas VIII B SMP N 1 Banjarejo Kabupaten Blora" yang dilakukan oleh Jimstark (2012) membuktikan bahwa keterampilan siswa dalam menulis berita mengalami peningkatan setelah menggunakan strategi DS-SI. Selisih nilai rata-rata antara siklus I dan siklus II sebesar 19,025. Selain itu, siswa juga mengalami perubahan perilaku belajar. Sedangkan hasil penelitian Asih (2012) yang berjudul "Peningkatan Keterampilan Menulis Teks Berita dengan Pendekatan Kontekstual Komponen Inkuiri Melalui Media Kubus Pintar pada Sisa Kelas VIII SMP N 1 Ampelgading Kabupaten Pemalang" membuktikan bahwa keterampilan menulis berita siswa mengalami peningkatan sebesar 12,67 atau 20,24\%. Selain itu, perilaku siswa juga mengalami perubahan positif.

Terkait dengan hal tersebut, salah satu upaya untuk menumbuhkan minat siswa terhadap menulis berita dapat dilakukan dengan mengembangkan sebuah produk bahan ajar. Bahan ajar yang dikembangkan harus mampu memenuhi kebutuhan siswa terhadap teori dan praktik menulis berita. Bahan ajar yang akan dikembangkan ini merupakan bahan ajar yang dikemas dalam bentuk buku. Bahan ajar ini dipadukan dengan berbagai peristiwa multikultural yang ada di Indonesia. Hal ini dimaksudkan agar siswa mulai memahami pendidikan multikultural sejak dini. Peristiwa multikultural dalam bahan ajar peneliti sajikan melalui ilustrasi teks, gambar, dan contoh-contoh berita.
Melalui bahan ajar yang dikembangkan, peneliti mengharapkan agar siswa makin tertarik pada berita dan termotivasi untuk kreatif menghasilkan produk berita. Selain itu, pemahaman multikultural siswa diharapkan bertambah sehingga wawasan kebangsaan siswa pun makin luas. Dalam penelitian ini, peneliti akan mengembangkan bahan ajar menulis berita. Tujuan penelitian ini adalah untuk mengembangkan bahan ajar menulis teks berita pada siswa kelas VIII SMP, dan untuk mengetahui keefektifan bahan ajar menulis berita multikultural pada siswa kelas VIII SMP.

\section{B. METODE}

Jenis penelitian ini adalah penelitian pengembangan (research and development). Penelitian pengembangan adalah jenis penelitian yang berorientasi pada pengembangan produk. Penelitian ini menggunakan penelitian pengembangan. Borg \& Gall (dalam Sugiyono, 2010) menyatakan bahwa penelitian dan pengembangan merupakan metode penelitian yang digunakan untuk mengembangkan atau memvalidasi produk-produk yang digunakan dalam pendidikan dan pembelajaran. Penelitian pengembangan ini dilaksanakan di SMP Negeri 8 Penajam Paser Utara. Pelaksanaan penelitian pengembangan ini dimulai pada pertengahan bulan April hingga Mei 2019, disesuaikan pada jadwal pembelajaran semester genap. Obyek penelitian ini adalah hasil belajar siswa mata pelajaran Bahasa Indonesia, khususnya pada kompetensi dasar menulis berita. Sedangkan subyek dalam pelaksanaan penelitian ini yaitu siswa kelas VIII SMP Negeri 8 penajam Paser Utara yang berjumlah 26 siswa.

Teknik pengambilan data yang digunakan adalah penyebaran angket (kuesioner) dan observasi. Angket diberikan kepada responden untuk menjawab pertanyaan yang diberikan peneliti mengenai bahan ajar atau produk. 
Responden ini yang nantinya akan menjadi penguji (validator) dari prototipe produk yang sudah dirancang. Instrumen dalam penelitian ini adalah lembar angket penelitian mengenai kelayakan bahan berita multikultural sebagai sumber belajar. Instrumen tersebut disusun untuk mengetahui kelayakan dan kemenarikan bahan ajar yang dikembangkan. Instrumen penelitian untuk uji validasi tim ahli materi, bahasa, dan grafika yang digunakan pada penelitian ini berisi pertanyaan. Angket ini digunakan untuk memperoleh data tentang kelayakan, kejelasan, dan kebenaran materi yang disajikan dalam produk bahan ajar menulis berita peristiwa multikultural.

\section{PEMBAHASAN}

\section{Tahap Pengembangan Bahan Ajar}

Tahapan dalam pengembangan bahan ajar adalah sebagai berikut. Pertama, menyusun rencana pengembangan bahan ajar menulis teks berita. Dalam pengamatan peneliti, pembuatan bahan ajar menulis teks berita multikultural dapat dibutuhkan sebuah acuan dalam pembuatan bahan ajar tersebut yang baik. Bahan ajar yang dikembangkan adalah sebuah buku yang ditulis dengan tujuan agar siswa dapat belajar secara mandiri tanpa atau dengan bimbingan guru. Dengan menggunakan bahan ajar guru dan siswa dapat menyiasati waktu selama proses belajar mengajar berlangsung. Materi pelajaran tidak hanya dilakukan di dalam kelas tetapi dapat juga memanfaatkan waktu di luar jam belajar dan di luar kelas.

Terdapat berbagai jenis sistematika dalam penulisan bahan ajar yang masingmasing mempunyai karakteristik. Peneliti menggabungkan berbagai sistematika dalam penulisan bahan ajar yang dikembangkan sesuai dengan kebutuhan siswa sehingga bahan ajar yang dikembangkan dapat mempermudah peserta didik dan guru dalam proses belajar mengajar.

Kedua, menentukan isi bahan ajar. Pengembangan bahan ajar pembelajaran Bahasa Indonesia materi menulis teks berita yang disusun menggunakan sumber-sumber acuan. Penentuan isi modul terdiri atas pemilihan tema, teks berita, indikator, materi, juga langkahlangkah pembelajaran.

Ketiga, menentukan desain produk mata pelajaran bahasa Indonesia. Saat observasi awal untuk mengetahui apa yang dibutuhkan di lapangan dalam pembelajaran Bahasa Indonesia, peneliti memperoleh hasil bahwa kurang berhasilnya pembelajaran Bahasa Indonesia disebabkan oleh penerapan metode atau model pembelajaran yang masih monoton, berpusat pada guru (teacher-centered) belum berpusat pada siswa (student-centered) dan buku pendukung pelajaran yang kurang menarik.

Dampak dari pembelajaran tersebut adalah siswa merasa jenuh dan kurang bersemangat dan tidak terjadi komunikasi dua arah antara guru dan siswa. Siswa menjadi kurang menyukai pelajaran Bahasa Indonesia. Selain itu guru juga dalam proses belajar mengajar hanya menggunakan dan memanfaatkan bukubuku yang ada tanpa menggunakan buku pendukung pelajaran yang dapat dimanfaatkan siswa secara maksimal. Akibatnya proses belajar mengajar menjadi semacam rutinitas yang terlewatkan begitu saja tanpa kesan yang mendalam bagi siswa.

\section{Pelaksanaan Uji Coba Produk a. Uji Coba Kelompok Kecil Pertama \\ Uji coba kelompok kecil pertama} kelas VIII berjumlah 3 siswa, dengan tujuan mengetahui kelebihan dan kekurangan yang ada pada produk modul pembelajaran bahasa Indonesia menulis teks berita. Dari hasil uji coba kelompok kecil pertama data digunakan sebagai 
masukan untuk melakukan revisi sebelum produk digunakan untuk uji coba kelompok kecil.

Berdasarkan Tabel 1, nilai tes kognitif pada uji kelompok kecil pertama diperoleh nilai pada pertemuan ke-1, nilai rata-rata 76 dan persentase ketuntasan $66,7 \%$. Sedangkan pertemuan ke-2, nilai rata-rata 83,3 dan persentase ketuntasan 100\%. Tabel 2 menunjukkan nilai tes psikomotorik pada uji kelompok kecil pertama. Pada tes psikomotorik pertemuan ke-1 diperoleh nilai rata-rata 74,3 dan persentase ketuntasan $66,7 \%$. Sedangkan pada pertemuan ke-2, nilai rata-rata 80,7 dan persentase ketuntasan $100 \%$. Nilai tes afektif, sebagaimana data Tabel 3, uji kelompok kecil pertama diperoleh nilai rata-rata 2,7 dan persentase ketuntasan 90,3\%.

Tabel 1. Nilai Tes Kognitif pada Uji Coba Kelompok Kecil Pertama

\begin{tabular}{clcc}
\hline No. & Nama Siswa & $\begin{array}{c}\text { Nilai Hasil Tes Pertemuan 1 } \\
\text { (KKM 75) }\end{array}$ & $\begin{array}{c}\text { Nilai Hasil Tes Pertemuan 2 } \\
\text { (KKM 75) }\end{array}$ \\
\hline 1. & FNL & 76 & 80 \\
2. & SHA & 72 & 80 \\
3. & AH & 80 & 90 \\
\hline & Jumlah & $\mathbf{2 2 8}$ & $\mathbf{2 5 0}$ \\
\hline & Nilai rata-rata & $\mathbf{7 6}$ & $\mathbf{8 3 , 3}$ \\
\hline & Persentase ketuntasan & $\mathbf{6 6 , 7}$ & $\mathbf{1 0 0}$ \\
\hline
\end{tabular}

Tabel 2. Nilai Tes Psikomotorik pada Uji Coba Kelompok Kecil Pertama

\begin{tabular}{clcc}
\hline No. & \multicolumn{1}{c}{ Nama Siswa } & $\begin{array}{c}\text { Nilai Hasil Tes Pertemuan 1 } \\
\text { (KKM 75) }\end{array}$ & $\begin{array}{c}\text { Nilai Hasil Tes Pertemuan 2 } \\
\text { (KKM 75) }\end{array}$ \\
\hline 1. & FNL & 75 & 80 \\
2. & NSA & 78 & 82 \\
3. & AH & 70 & 80 \\
\hline & Jumlah & $\mathbf{2 2 3}$ & $\mathbf{2 4 2}$ \\
\hline & Nilai rata-rata & $\mathbf{7 4 , 3}$ & $\mathbf{8 0 , 7}$ \\
\hline & Persentase ketuntasan & $\mathbf{6 6 , 7}$ & $\mathbf{1 0 0}$ \\
\hline & Kategori & Cukup & Sangat baik \\
\hline
\end{tabular}

Tabel 3. Nilai Tes Afektif pada Uji Coba Kelompok Kecil Pertama

\begin{tabular}{|c|c|c|c|c|c|c|}
\hline \multirow{2}{*}{ No. } & \multirow{2}{*}{ Pertanyaan } & \multicolumn{3}{|c|}{ Siswa (Peserta Didik) } & \multirow{2}{*}{ Jumlah } & \multirow{2}{*}{ Rata-Rata } \\
\hline & & 1 & 2 & 3 & & \\
\hline 1. & $\begin{array}{l}\text { Apakah siswa bertanggung jawab dengan } \\
\text { pekerjaan yang Anda lakukan? }\end{array}$ & 3 & 3 & 3 & 9 & 3.0 \\
\hline 2. & $\begin{array}{l}\text { Jika diberi tugas oleh guru apakah dikerjakan } \\
\text { dengan senang hati? }\end{array}$ & 3 & 2 & 3 & 8 & 2.7 \\
\hline 3. & $\begin{array}{l}\text { Bila teman mengalami } \\
\text { mengerjakan tugas } \\
\text { membantunya? }\end{array}$ & 3 & 2 & 3 & 8 & 2,7 \\
\hline 4. & $\begin{array}{l}\text { Apakah Anda memilih teman dalam } \\
\text { membantunya? }\end{array}$ & 3 & 3 & 3 & 9 & 3.0 \\
\hline 5. & $\begin{array}{l}\text { Apakah Anda membantu teman siapa saja } \\
\text { yang memerlukan bantuan? }\end{array}$ & 2 & 3 & 2 & 7 & 2,3 \\
\hline 6. & $\begin{array}{l}\text { Apakah Anda selalu meminta maaf jika } \\
\text { melakukan kesalahan? }\end{array}$ & 2 & 3 & 3 & 8 & 2,7 \\
\hline 7. & $\begin{array}{l}\text { Jika bertemu orang yang lebih tua apakah } \\
\text { Anda akan menyapanya? }\end{array}$ & 3 & 3 & 2 & 8 & 2.7 \\
\hline 8. & $\begin{array}{l}\text { Jika bertemu seseorang yang lebih muda, } \\
\text { apakah Anda juga menyapanya? }\end{array}$ & 2 & 3 & 3 & 8 & 2.7 \\
\hline & Jumlah & 21 & 22 & 22 & 65 & 21,8 \\
\hline & Rata-rata & 2,6 & 2,8 & 2,8 & 8,1 & 2,7 \\
\hline & Persentase ketuntasan (\%) & 87,5 & 91,7 & 91,7 & 90,3 & \\
\hline
\end{tabular}




\section{b. Uji Coba Kelompok Kecil Kedua}

Uji kelompok kecil kedua yang dilakukan menggunakan siswa sebanyak 10 orang dengan karakteristik yang berbeda baik dalam hal kemampuan di mana terdapat siswa dengan kemampuan rendah, siswa dengan kemampuan sedang dan siswa dengan kemampuan tinggi. Responden bervariasi terdiri dari laki-laki dan perempuan. Berdasarkan nilai tes kognitif pada uji kelompok kecil kedua sebagaimana Tabel 4, diperoleh nilai ratarata pada pertemuan ke-1 adalah 75,5 dan persentase ketuntasan 75\%. Sedangkan pertemuan ke-2, nilai rata-rata 83,9 dan persentase ketuntasan $100 \%$. Nilai tes psikomotorik pada uji kelompok kecil kedua terlihat pada Tabel 5. Nilai tes psikomotorik pada uji ini, pada pertemuan ke-1 diperoleh nilai rata-rata 79,1 dan persentase ketuntasan 70\%. Sedangkan pada pertemuan ke-2, nilai rata-rata 81,7 dan persentase ketuntasan 100\%. Berdasarkan Tabel 6, nilai tes afektif pada uji kelompok kecil kedua diperoleh nilai rata-rata 2,7 dan persentase ketuntasan 89,6\% dengan kategori baik.

Tabel 4. Nilai Kognitif Siswa pada Uji Coba Kelompok Kecil Kedua

\begin{tabular}{clcc}
\hline No. & Nama Siswa & $\begin{array}{c}\text { Nilai Hasil Tes Pertemuan 1 } \\
(\text { KKM 75) }\end{array}$ & $\begin{array}{c}\text { Nilai Hasil Tes Pertemuan 2 } \\
\text { (KKM 75) }\end{array}$ \\
\hline 1. & A & 75 & 80 \\
2. & A HL & 70 & 85 \\
3. & AW & 80 & 88 \\
4. & BY & 73 & 80 \\
5. & CK & 78 & 80 \\
6. & INM & 80 & 89 \\
7. & LABL & 80 & 89 \\
8. & NTR & 79 & 83 \\
9. & RA & 70 & 80 \\
10. & SCP & 70 & 85 \\
\hline \multicolumn{2}{r}{ Jumlah } & $\mathbf{7 5 5}$ & $\mathbf{8 3 9}$ \\
\hline \multicolumn{2}{r}{ Pilai rata-rata } & $\mathbf{7 5 , 5}$ & $\mathbf{8 3 , 9}$ \\
\hline
\end{tabular}

Tabel 5. Nilai Psikomotorik Siswa pada Uji Coba Kelompok Kecil Kedua

\begin{tabular}{|c|c|c|c|}
\hline No. & Nama Siswa & $\begin{array}{c}\text { Nilai Hasil Tes Pertemuan } 1 \\
\text { (KKM 75) }\end{array}$ & $\begin{array}{c}\text { Nilai Hasil Tes Pertemuan } 2 \\
\text { (KKM 75) }\end{array}$ \\
\hline 1. & $\mathrm{~A}$ & 77 & 78 \\
\hline 2. & A HL & 76 & 80 \\
\hline 3. & AW & 84 & 85 \\
\hline 4. & BY & 80 & 85 \\
\hline 5. & CK & 79 & 80 \\
\hline 6. & INM & 80 & 83 \\
\hline 7. & LABL & 80 & 85 \\
\hline 8. & NTR & 80 & 83 \\
\hline 9. & RA & 75 & 78 \\
\hline \multirow[t]{5}{*}{10.} & SCP & 80 & 80 \\
\hline & Jumlah & 791 & 817 \\
\hline & Nilai rata-rata & 79,1 & 81,7 \\
\hline & Persentase ketuntasan & 70 & 100 \\
\hline & Kategori & Cukup & Sangat Baik \\
\hline
\end{tabular}


Tabel 6. Nilai Tes Afektif pada Uji Coba Kelompok Kecil Kedua

\begin{tabular}{|c|c|c|c|}
\hline No. & Pertanyaan & Jumlah & Rata-rata \\
\hline 1. & $\begin{array}{l}\text { Apakah Anda bertanggung jawab dengan pekerjaan yang Anda } \\
\text { lakukan? }\end{array}$ & 27 & 2,8 \\
\hline 2. & $\begin{array}{l}\text { Jika diberi tugas oleh guru apakah dikerjakan dengan senang } \\
\text { hati? }\end{array}$ & 25 & 2,6 \\
\hline 3. & $\begin{array}{l}\text { Bila teman mengalami kesulitan dalam mengerjakan tugas } \\
\text { apakah Anda membantunya? }\end{array}$ & 27 & 2,8 \\
\hline 4. & Apakah Anda memilih teman dalam membantunya? & 28 & 2,8 \\
\hline 5. & $\begin{array}{l}\text { Apakah Anda membantu teman siapa saja yang memerlukan } \\
\text { bantuan? }\end{array}$ & 28 & 2,8 \\
\hline 6. & Apakah Anda selalu meminta maaf jika melakukan kesalahan? & 28 & 2,8 \\
\hline 7. & $\begin{array}{l}\text { Jika bertemu orang yang lebih tua apakah Anda akan } \\
\text { menyapanya? }\end{array}$ & 28 & 2,8 \\
\hline 8. & $\begin{array}{l}\text { Jika bertemu seseorang yang lebih muda, apakah Anda juga } \\
\text { menyapanya? }\end{array}$ & 24 & 2,6 \\
\hline & Jumlah & 2,15 & \\
\hline & Rata-rata & 2,7 & 2,7 \\
\hline & Persentase ketuntasan & \multicolumn{2}{|c|}{89,6} \\
\hline & Kategori & \multicolumn{2}{|c|}{ Sangat baik } \\
\hline \multicolumn{4}{|c|}{ Tabel 7. Data Hasil Belajar Aspek Kognitif Siswa pada Uji Lapangan } \\
\hline No. & $\begin{array}{cc}\text { Nama Siswa } & \text { Nilai Hasil Tes Pertemuan 1 } \\
(\text { KKM 75) }\end{array}$ & \multicolumn{2}{|c|}{$\begin{array}{c}\text { Nilai Hasil Tes Pertemuan } 2 \\
\text { (KKM 75) }\end{array}$} \\
\hline 1. & DAS & \multicolumn{2}{|c|}{80} \\
\hline 2. & EDA & \multicolumn{2}{|c|}{80} \\
\hline 3. & EDS & \multicolumn{2}{|c|}{90} \\
\hline 4. & FTK & \multicolumn{2}{|c|}{80} \\
\hline 5. & FN & \multicolumn{2}{|c|}{85} \\
\hline 6. & FR & \multicolumn{2}{|c|}{90} \\
\hline 7. & $\mathrm{HN}$ & \multicolumn{2}{|c|}{85} \\
\hline 8. & 70 & \multicolumn{2}{|c|}{85} \\
\hline 9. & MNS & \multicolumn{2}{|c|}{85} \\
\hline 10. & $\mathrm{AW}$ & \multicolumn{2}{|c|}{85} \\
\hline 11. & BY & \multicolumn{2}{|c|}{90} \\
\hline 12. & CK & \multicolumn{2}{|c|}{90} \\
\hline 13. & INP & \multicolumn{2}{|c|}{85} \\
\hline 14. & NTR & \multicolumn{2}{|c|}{80} \\
\hline 15. & $\mathrm{AH}$ & \multicolumn{2}{|c|}{80} \\
\hline 16. & $\mathrm{RA}$ & \multicolumn{2}{|c|}{85} \\
\hline 17. & SCP & \multicolumn{2}{|c|}{85} \\
\hline 18. & LA & \multicolumn{2}{|c|}{85} \\
\hline 19. & MY & \multicolumn{2}{|c|}{85} \\
\hline 20. & MPA & \multicolumn{2}{|c|}{80} \\
\hline 21. & MJA & \multicolumn{2}{|c|}{90} \\
\hline 23. & NS & \multicolumn{2}{|c|}{85} \\
\hline 24. & NSA & & \\
\hline 25. & 80 & & \\
\hline 26. & $\mathrm{AH}$ & & \\
\hline & Jumlah & & \\
\hline & Nilai rata-rata & & \\
\hline & Persentase & & \\
\hline
\end{tabular}


Tabel 8. Data Hasil Belajar Aspek Psikomotorik Siswa pada Uji Lapangan

\begin{tabular}{|c|c|c|c|}
\hline No. & Nama Siswa & $\begin{array}{c}\text { Nilai Hasil Tes Pertemuan } 1 \\
\text { (KKM 75) }\end{array}$ & $\begin{array}{c}\text { Nilai Hasil Tes Pertemuan } 2 \\
\text { (KKM 75) }\end{array}$ \\
\hline 1. & DAS & 80 & 78 \\
\hline 2. & EDA & 76 & 80 \\
\hline 3. & EDS & 80 & 90 \\
\hline 4 & FTK & 75 & 83 \\
\hline 5 & $\mathrm{FN}$ & 79 & 85 \\
\hline 6 & FR & 86 & 90 \\
\hline 7 & $\mathrm{HN}$ & 80 & 85 \\
\hline 8 & IF & 74 & 80 \\
\hline 9 & MNS & 79 & 85 \\
\hline 10 & AW & 80 & 85 \\
\hline 11 & BY & 85 & 90 \\
\hline 12 & $\mathrm{CK}$ & 85 & 90 \\
\hline 13 & INP & 78 & 80 \\
\hline 14 & NTR & 79 & 80 \\
\hline 15 & $\mathrm{AH}$ & 75 & 80 \\
\hline 16 & RA & 80 & 85 \\
\hline 17 & SCP & 79 & 83 \\
\hline 18 & LA & 85 & 85 \\
\hline 19 & MY & 80 & 85 \\
\hline 20 & MPA & 77 & 87 \\
\hline 21 & MJA & 85 & 87 \\
\hline 23 & NS & 82 & 85 \\
\hline 24 & NSA & 80 & 85 \\
\hline 25 & $\mathrm{H}$ & 80 & 80 \\
\hline 26 & $\mathrm{AH}$ & 70 & 77 \\
\hline & Jumlah & 1990 & 2100 \\
\hline & Nilai rata-rata & 76,6 & 80,8 \\
\hline & Persentase ketuntasan & $92,30 \%$ & $100 \%$ \\
\hline
\end{tabular}

Tabel 9. Nilai Aspek Apektif Siswa Pada Uji Lapangan

\begin{tabular}{clcc}
\hline \multirow{2}{*}{ No. } & \multicolumn{1}{c}{ Pertanyaan } & Jumlah & Rata-rata \\
\hline 1. & Apakah Anda bertanggung jawab dengan pekerjaan yang Anda lakukan? & 83 & $\mathbf{3 , 2}$ \\
2. & Jika diberi tugas oleh guru apakah dikerjakan dengan senang hati & 75 & $\mathbf{2 , 9}$ \\
3. & Bila teman mengalami kesulitan dalam mengerjakan tugas apakah Anda & 78 & $\mathbf{3 , 0}$ \\
& membantunya? & 75 & $\mathbf{2 , 9}$ \\
4. & Apakah Anda memilih teman dalam membantunya? & 78 & $\mathbf{3 , 0}$ \\
5. & Apakah Anda membantu teman siapa saja yang memerlukan bantuan? & 82 & $\mathbf{3 , 2}$ \\
6. & Apakah Anda selalu meminta maaf jika melakukan kesalahan? & 79 & $\mathbf{3 , 0}$ \\
7. & Jika bertemu orang yang lebih tua apakah Anda akan menyapanya? & 83 & $\mathbf{3 , 2}$ \\
8. & Jika bertemu seseorang yang lebih muda, apakah Anda juga menyapanya? & $\mathbf{6 3 3}$ & $\mathbf{2 4 , 3 5}$ \\
\hline & Jumlah & $\mathbf{2 4 , 3 5}$ & $\mathbf{2 4 , 3 5}$ \\
\hline & Rata-rata & $\mathbf{9 3 , 6 \%}$ \\
\hline & Persentase ketuntasan & \multicolumn{2}{c}{ Sangat baik } \\
\hline
\end{tabular}

c. Uji Lapangan (Uji Pemakaian)

Pengujian tahap ini dilakukan dengan juga uji kelompok besar atau uji pemakaian atau disebut uji lapangan. Uji kelompok besar dilakukan pada siswa SMP Negeri 8 Penajam Paser Utara dengan sampel sebanyak 26 peserta didik. Proses pembelajaran pertemuan pertama dilakukan pada hari Sabtu, 29 April 2109. Adapun hasil belajar siswa untuk aspek kognitif pada pertemuan pertama adalah sebagai berikut. Berdasarkan hasil nilai tes 
yang disajikan pada Tabel 7, maka dapat dilihat bahwa dari 26 siswa, sebanyak 3 siswa tidak tuntas karena nilai hasil belajar kurang dari KKM 75 atau ketuntasan klasikal sebesar 88,46\%, yang berarti ketuntasan klasikal tercapai dengan nilai rata-rata kelas 79,2. Setelah dilakukan perbaikan dalam pembelajaran menggunakan modul pembelajaran bahasa Indonesia teks berita, pada pertemuan kedua yang dilakukan pada tanggal 1 Mei 2019 pada saat kegiatan belajar mengajar diberikan tes kognitif pada siswa. Pada pertemuan kedua dari 26 siswa, semua mengalami ketuntasan karena nilai hasil belajar lebih besar dari KKM 75 atau ketuntasan klasikal sebesar $100 \%$, yang berarti ketuntasan klasikal sudah tercapai dengan nilai rata-rata kelas 84,8 .

Proses perolehan nilai psikomotorik (Tabel 8) diambil dari pembelajaran pertemuan pertama dilakukan pada tanggal 2 Mei 2019. Adapun hasil belajar siswa untuk psikomotorik yang diambil dari tugas yang dikerjakan secara kelompok, pada pertemuan pertama adalah sebagai berikut. Berdasarkan hasil nilai tes yang disajikan pada tabel di atas, maka dapat dilihat bahwa dari 26 siswa, terdapat 2 siswa tidak tuntas karena nilai hasil belajar kurang dari KKM 75 atau ketuntasan klasikal sebesar 92,30\% yang berarti ketuntasan klasikal telah mencapai dengan nilai rata-rata kelas 76,6. Untuk memperbaiki hasil belajar siswa, guru melakukan perbaikan pada proses belajar mengajar dan mengajarkan siswa untuk memanfaatkan modul pembelajaran dengan baik dan memperbaiki langkah-langkah agar kegiatan belajar mengajar menjadi efektif. Karena pekerjaan dilakukan secara kelompok, siswa dituntut untuk lebih bekerja sama dan untuk dapat lebih memahami materi pelajaran.

Pada pertemuan kedua yang dilakukan pada tanggal 7 Mei 2019, dapat dilihat bahwa 26 siswa mencapai ketuntasan. Dengan penggunaan pembelajaran berbasis gambar yang dilakukan di luar kelas dengan teman sekelompok, mereka merasa lebih bersemangat dan senang. Nilai hasil belajar lebih besar dari KKM 75 atau ketuntasan klasikal sebesar 100\%, yang berarti ketuntasan klasikal sudah tercapai dengan nilai rata-rata kelas 80,8 .

Berdasarkan hasil nilai tes afektif (Tabel 9) yang disajikan pada Tabel 9, dapat dilihat hasil keseluruhan nilai sikap pada 26 siswa adalah 24,35 dengan persentase $90,6 \%$.

\section{Efektivitas Hasil Belajar Siswa}

Penilaian efektivitas hasil belajar siswa menunjukkan hasil yang diharapkan, yakni sesuai dengan kriteria ketuntasan hasil belajar kurang dari KKM 75 atau ketuntasan klasikal sebesar $70 \%$. Nilai hasil belajar siswa diperoleh nilai rata-rata 83,5 dengan persentase 91,9\% termasuk kategori sangat baik. Untuk nilai aspek kognitif diperolah nilai rata-rata 80,6 dengan persentase $85,9 \%$ termasuk kategori baik. Untuk nilai aspek psikomotorik diperolah nilai rata-rata 78,9 dengan persentase 89,7\% termasuk kategori sangat baik. Untuk nilai aspek afektif diperolah nilai rata-rata 91 dengan persentase $100 \%$ termasuk kategori sangat baik. Hal tersebut menunjukkan bahwa modul pembelajaran menulis teks berita efektif digunakan oleh siswa pada proses belajar mengajar menulis teks berita pada siswa kelas VIII SMP.

Tabel 10. Efektivitas Hasil Belajar Siswa

\begin{tabular}{clccc}
\hline No. & \multicolumn{1}{c}{ Hasil Belajar } & Nilai Rata-rata & Persentase & Kategori \\
\hline 1. & Kognitif & 80,5 & $85,9 \%$ & Baik \\
2. & Psikomotorik & 78,9 & $89,7 \%$ & sangat Baik \\
3. & Afektif & 91 & $100 \%$ & Sangat Baik \\
\hline & Jumlah & $\mathbf{8 3 , 5}$ & $\mathbf{9 1 , 9 \%}$ & Sangat Baik \\
\hline
\end{tabular}




\section{PENUTUP}

Hasil pengembangan modul pembelajaran menulis berita dengan pendekatan kontekstual berbasis gambar pada siswa VIII SMP dilakukan melalui uji validasi oleh parah ahli dan uji coba produk. Kevalidan dan modul untuk pembelajaran dilihat dari isi, penyajian, bahasa dan kegrafikan melalui uji ahli materi dan bahasa, ahli desain grafis dan ahli teks berita dengan kategori layak digunakan dengan perolehan nilai dari ahli materi pada tahap I sebesar 77,5\% dan tahap II sebesar 92,9\% dengan kategori layak. Kemudian dari ahli bahasa melalui uji validitas tahap I diperoleh nilai sebesar $72 \%$ dan validitas tahap II sebesar 92\% dengan kategori layak. Sedangkan dari uji validitas ahli grafika diperoleh nilai sebesar 78\% pada tahap I dan selanjutnya pada uji validitas tahap II diperoleh nilai sebesar $98 \%$ dengan kategori sangat layak.

Dari hasil uji validitas produk bahan ajar dan pelaksanaan uji coba produk pada uji coba kelompok kecil (terbatas) dan kelompok besar (uji lapangan) didapatkan efektivitas bahan ajar menulis berita siswa SMP Kelas VIII. Uji validitas dilakukan berdasarkan hasil tes belajar siswa dari beberapa tes yaitu kognitif, psikomotorik, dan afektif. Dari hasil tes belajar siswa secara keseluruhan didapatkan nilai rata-rata sebesar 83,5 dengan persentase sebesar 100\%. Dengan demikian efektivitas bahan ajar dan kualitas belajar siswa dengan menggunakan bahan ajar menulis berita di nilai efektif dan masuk dalam kategori baik.

\section{DAFTAR PUSTAKA}

Akhadiah, S., Arsyad, M. G., \& Ridwan, S. H. (1998). Model pengembangan Borg \& Gall. Jakarta: Erlangga.

Asih, T. (2012). Peningkatan Keterampilan Menulis Teks Berita dengan Pendekatan Kontekstual Komponen Inkuiri Melalui
Media Kubus Pintar pada Siswa Kelas VIII SMP Negeri 1 Ampelgading. Universitas Negeri Semarang. https://lib.unnes.ac.id/14532/

Jimstark, N. C. D. (2012). Peningkatan Keterampilan Menulis Teks Berita melalui Strategi Menulis Di Sini dan Saat Ini (DS-SI) dengan Media Foto Jurnalistik. Siswa Kelas VIII B SMP N 1 Banjarejo Kabupaten Blora. Universitas Negeri Semarang. https://lib.unnes.ac.id/13788/

Moleong, L. J. (2012). Metodologi Penelitian Kualitatif. Bandung: Remaja Rosdakarya

Musaba, Z., \& Siddik, M. (2017). DasarDasar Keterampilan Menulis. Yogyakarta: Aswaja Pressindo.

Nurhana, Siddik, M., \& Ridhani, A. (2020). Pengembangan Bahan Ajar Menulis Cerpen dengan Teknik Parafrase pada Peserta Didik Kelas XI MAN 2 Samarinda. Diglosia: Jurnal Kajian Babasa, Sastra, Dan Pengajarannya, 3(2), 211-220. https://doi.org/10.30872/diglosia.v 3i2.63

Prastowo, A. (2015). Panduan Kreatif Membuat Bahan Ajar Inovatif. Yogyakarta: Diva Press.

Rohmadi, M., \& Nasucha, Y. (2010). Paragraf Pengembangan dan Implementasi. Yogyakarta: Media Perkasa.

Sugiyono. (2017). Metode Penelitian dan Pengembangan (Research and Development/R\&D). $\quad$ Bandung: Alfabeta.

Sutriyati, Mulawarman, W. G., \& Hudiyono, Y. (2019). Pengembangan Bahan Ajar Menulis Esai Dengan Memanfaatkan Kearifan Lokal Melalui Pembelajaran Berbasis Proyek (PBP) Siswa SMA. Diglosia: Jurnal Kajian Bahasa, Sastra, Dan Pengajarannya, 2(1), 39-46. https://doi.org/10.30872/diglosia.v $2 \mathrm{i} 1.16$ 
Tarigan, H. G. (2013). Menulis sebagai Suatu Keterampilan Berbahasa. Bandung: Angkasa.

Yulianti, K. (2011). Peningkatan Keterampilan Menulis Teks Berita menggunakan Metode Investigasi
Kelompok dengan Pemanfaatan Media Foto Peristiwa pada Siswa Kelas VIII F SMP Negeri 28 Semarang. Universitas Negeri Semarang. https://lib.unnes.ac.id/12795/ 
